\title{
BACTERIAL PROFILE OF BILE CULTURE FROM PATIENTS UNDERGOING CHOLECYSTECTOMY
}

\author{
Fatima A. Chaloob \\ Al-Dewaniyah Technical Institute, Al-Furat Al-Awsat Technical University/Iraq \\ e-mail:dw.ftm@atu.edu.iq
}

\begin{abstract}
Laparoscopic cholecystectomy is the most commonly performed routine surgical operation in general surgery. There is a debate about utility of prophylactic antibiotic therapy following cholecystectomy. The aim of the study was to investigate bacterial growth in bile culture from patients after laparoscopic cholecystectomy. Methods. This study included 80 patients who undergone laparoscopic cholecystectomy. All gallbladder specimens were sent for histopathology. A bile sample from each case was cultured on Brain heart infusion broth, MacConkey agar, and chocolate agar. Analytical profile indices were used for identification of isolated bacteria. Results. Six histopathological abnormalities were detected, of which chronic cholecystitis was the most common abnormality (58.75\%) followed by acute cholecystitis with mucocele (11.25\%). Thirty one bile samples (38.75\%) were positive for bacterial growth. The overall bacterial isolates from bile samples showed Escherichia coli, 13.75\%, Pseudomonas aeruginosa, 8.75\%, Enterococcus faecium, 5\%, Citrobacter freundii, 3.7\%, Staphylococcus epidermidis, $3.75 \%$, Lactobacillus gasseri, $2.5 \%$ and Bifidobacterium, $1.25 \%$. Bacterial colonization of gallbladder was significantly associated with acute cholecystitis with mucocele and empyema. Conclusions. More than one third of patients with cholelithiasis are positive for bacterial culture. Bacterial infection of stoned gallbladder associated with the development of empyema. Thus, prophylactic antibiotic therapy is recommended for patients undergoing cholecystectomy due to gallbladder stone.
\end{abstract}

Keywords: cholecystectomy, bacterial colonization of gallbladder.

\section{Introduction}

Acute cholecystitis is one of the most common inpatient diagnoses at surgical wards [1], and it arises as complications of cholelithiasis in more than $90 \%$ of patients [2].

Studies in patients who undergo cholecystectomy for uncomplicated symptomatic cholelithiasis indicate the presence of bacteria in $20-46 \%$ of them, while healthy individuals are usually free from these bacteria [3]. Post-operative bacterial infection is of concern to surgeons. That is because wound infection occurs in $7 \%$ to $20 \%$ post cholecystectomy in uncomplicated symptomatic cholelithiasis [4]. Aerobic bacteria, facultative aerobes and anaerobes can invade the biliary ducts by the hematogenous route from the hepatic portal vein or by ascending from the duodenum [5].

Previous studies of bile culture at cholecystectomy for patients with uncomplicated cholelithiasis demonstrated the predominance of Gram-negative bacteria, mainly Escherichia coli, Pseudomonas spp., Enteroccocus faecalis, Streptococcus spp. and Klebsiella spp. [6].

Studies about the association between positive bile cultures and surgical infection are conflicting.
A recent report has disclosed a significant association between positivity for bile culture and the incidence of wound infection, as well as other severe septic complications [7]. Furthermore, there is a higher occurrence of postoperative complications and infections in patients who are positive for pathogenic bacteria in gallbladder (GB) bile compared with those with no bacterial growth of pathogenic or opportunistic bacteria. [8]. However, other bacteriological studies did not find a significant association between infected bile and postoperative complications for both laparoscopic and open cholecystectomy [9].

It should be noted that the possible role of a bacterial infection of the bile duct goes beyond simple wound infection. Rather, there is an important role of bacteria in the pathogenesis of cholesterol and pigment stone-containing bile. Supporting this assumption there is one study which reported the presence of DNA fragments of Gram-positive bacteria in $57 \%$ of pure cholesterol stones [10]. Thus, the prophylactic use of antibiotic post laparoscopic cholecystectomy (LC) is a matter of debate. 
This study aimed to evaluate the bacterial profile in bile culture in patients after LC and the association between the presence of bacteria and histopathological features of GB.

Patients and Methods. This cross sectional study included a total of 80 adult patients who were diagnosed as having acute or chronic cholecystitis secondary to cholelithiasis. Those patients attended the Surgery department/Al-Dewanyiya Teaching Hospital during the period from March to August 2020. Patients with evidence of GB carcinoma or those who were previously undergoing cholecystectomy were excluded from the study.

\section{Histopathology}

GB specimens were obtained from the patients and were fixed in $10 \%$ phosphate buffered formaldehyde, embedded in paraffin. The specimens were stained with hematoxylin and eosin. The excised GBs were undergone detailed macroscopic examination including length and integrity of $\mathrm{GB}$, presence or absence and type of microscopic lesions.

\section{Collection of Bile for Microbiological Study}

During the surgical operation, $2.5 \mathrm{~mL}$ of bile were aspirated. The sample was transferred to a sterile container and transferred at room temperature within an hour to the laboratory for microbiological studies.

Bile Culture and Bacterial Identification

Bile samples were immediately transferred to Brain heart infusion (BHI) medium vial which was prepared specially for bacterial cultivation, and were incubated at $37^{\circ} \mathrm{C}$. The samples then were subcultured aerobically on MacConkey media, while chocolate agar media was used for incubation in $\mathrm{CO}_{2}$ conditions. The initial reading was taken after 24 hours, while the final results were obtained after 72 hours. If there was no growth, the result was considered negative. Analytical profile indices API 20E, Api Staph system, API $50 \mathrm{CH}$ and API 20A (bio-Merieux, France) were used for identification of Enterobacteriaceae, staphylococci, Lactobacillus and Bifidobacterium, respectively. These systems can identify bacteria to species level.

\section{Antibiotic Sensitivity Tests}

Disc diffusion method (Kirby-Bauer) was used to examine the susceptibility of isolated bacteria to the most common antibiotics according to the Clinical and Laboratory Standard institute guidelines (CLSI). These antibiotics include: ampicillin, amoxicillin/ clavulanic acid, penicillin, gentamycin, sulfamethaxazole-trimethoprime, cephalexin, cephalothin, naldixic acid, nitrofurantoin, ciprofloxacin, ceftriaxone, amikacin and cefotaxime.

\section{Statistical Analyses}

Statistical analyses were carried out using SPSS version 25.0 (IBM, Chigaco, USA). Continuous variables were presented as the mean \pm standard deviation (SD). Binomial data were presented as frequency as well as percentages. Chi square/ Fisher's exact test was employed for comparison between binomial variables. The Student's t-test was used to compare two groups of continuous variables. A $p<0.05$ was considered statistically significant.

\section{Results}

\section{Demographic Characteristics of the Patients}

The mean age of patients at the time of surgery was $43.12 \pm 9.22$ years (range from 21 to 79 years). Out of 80 patients included in the study, $24(30 \%)$ were males, and $56(70 \%)$ were females. The male: female ratio was 1:2.3.

\section{Histopathological Findings}

According to histopathological reports, six histopathological abnormalities were detected, the most common of which was chronic cholecystitis accounting for 47 patients (58.75\%) followed by acute cholecystitis with mucocele $(11.25 \%)$ and acute cholecystitis with empyema $(7.5 \%)$. Less commonly reported cases of metaplasia/adenoma/ dysplasia (6.25\%), polyp (2.5\%) and one case of malignancy $(1.25 \%)$ as shown in Table 1.

\section{Table 1}

\begin{tabular}{|c|c|}
\hline \multicolumn{2}{|c}{ Histopathological Findings } \\
\hline Histopathological finding & $\begin{array}{c}\text { Frequency } \\
(\mathbf{\%})\end{array}$ \\
\hline Chronic cholecystitis & $47(58.75 \%)$ \\
\hline Acute cholecystitis with mucocele & $9(11.25 \%)$ \\
\hline Acute cholecystitis with empyema & $6(7.5 \%)$ \\
\hline Metaplasia/adenoma/dysplasia & $5(6.25 \%)$ \\
\hline Polyp & $2(2.5 \%)$ \\
\hline Malignancy & $1(1.25 \%)$ \\
\hline
\end{tabular}

\section{Bacterial Profile}

Thirty one bile samples out of 80 (38.75\%) were positive for bacteriological culture. The bacteriological profile of bile culture is shown in Fig. 1. E. coli was the most frequently identified bacteria, it was detected in 11 samples $(13.75 \%)$ followed by Pseudomonas aeruginosa in 7 samples $(8.75 \%)$ and Enterococcus faecium in 4 samples $(5 \%)$. Each of Citrobacter freundi and Staphylococcus epidermidis were identified in 
3 samples (3.75\%). Two bile samples (2.5\%) were found to have Lactobacillus gasseri, while one sample (1.25\%) involved Bifidobacterium.

Association of Bactibilia with Histopathological Features of the Patients

Patients were categorized into two groups according to the positivity for bacterial growth in the bile sample. The association of different histopathological features with the bactibilia was estimated. Two histopathological features were significantly associated with bactibilia. Firstly,
$22.58 \%$ of patients positive for bile culture had acute cholecystitis with mucocele compared with only $4.08 \%$ of patients negative for bacterial growth who had such pathology. Likewise, $19.35 \%$ of patients positive for bile culture had acute cholecystitis with empyema compared with only $2.44 \%$ of patients negative for bacterial growth who had such pathology with a highly significant difference (Table 2). On the other hand, there was no significant association between particular species of bacteria and histopathological features.

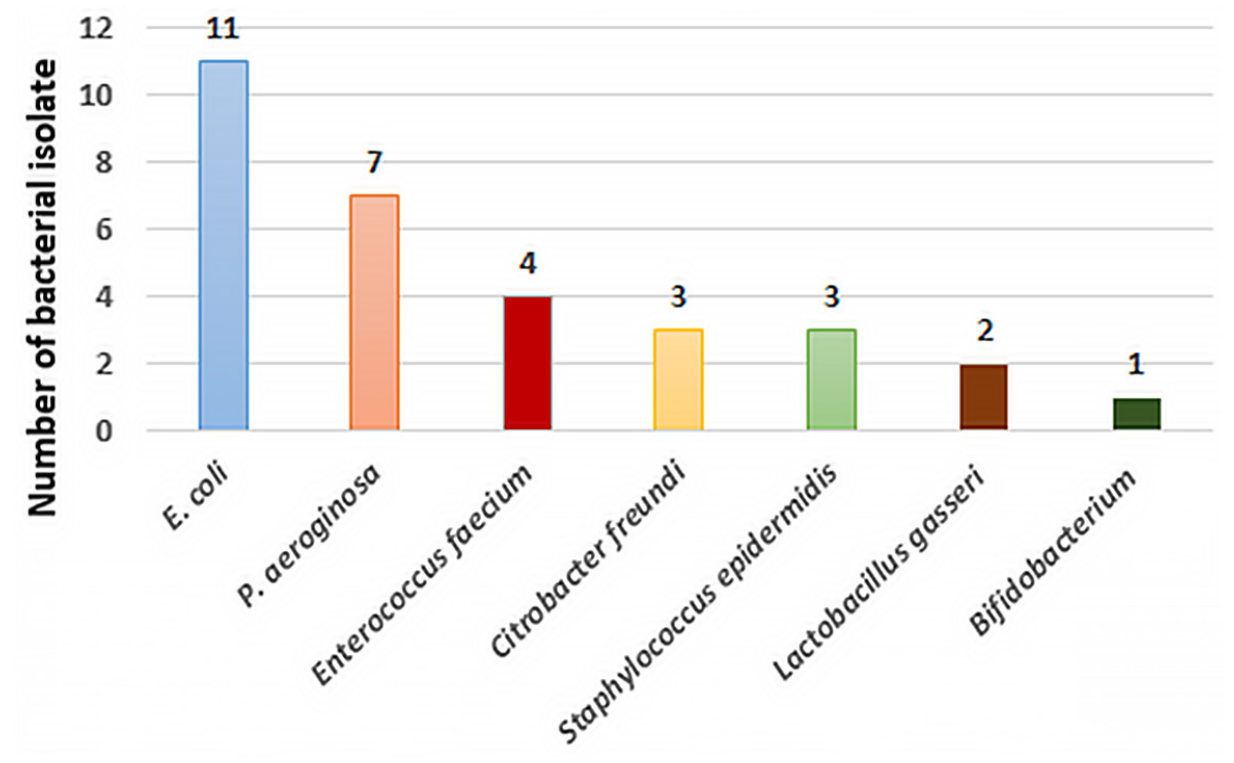

F i g. 1. Bacterial profile of bile samples from patients undergoing cholecystectomy

Table 2

Association of bactibilia histopathological features of the patients

\begin{tabular}{|l|c|c|c|}
\hline Histopathology & $\begin{array}{c}\text { Positive for bacterial } \\
\text { growth (n=31) }\end{array}$ & $\begin{array}{c}\text { Negative for bacterial } \\
\text { growth }(\mathbf{n}=\mathbf{4 9})\end{array}$ & p-value \\
\hline Chronic cholecystitis & $20(64.52 \%)$ & $27(55.1 \%)$ & 0.405 \\
\hline Acute cholecystitis with mucocele & $7(22.58 \%)$ & $2(4.08 \%)$ & $\mathbf{0 . 0 1 1}$ \\
\hline Acute cholecystitis with empyema & $6(19.35 \%)$ & $1(2.44 \%)$ & $\mathbf{0 . 0 0 8}$ \\
\hline Metaplasia/adenoma/dysplasia & $2(6.45 \%)$ & $3(6.12 \%)$ & 0.953 \\
\hline Polyp & $0(0 \%)$ & $2(4.08 \%)$ & 0.255 \\
\hline Malignancy & $1(3.23 \%)$ & $0(0 \%)$ & 0.206 \\
\hline
\end{tabular}

\section{Antibiotic Sensitivity}

With the exception of nitrofurantoin, amikacin and cefotaxime, E. coli isolates displayed high rate of resistance to all included antibiotic, with a resistance rate ranged from $54.55 \%$ (for gentamycin and naldixic acid) to $100 \%$ (for penicillin). $P$. aeruginosa also demonstrated a high resistance rate to almost all antibiotic except gentamycin and ciprofloxacin. Due to very low number of isolates of E. faecium, C. freundii and S. epidermidis, determination of their resistance to antibiotics is not necessarily representative. However, most isolates of these bacteria were resistant to penicillin and sulfamethaxazole-trimethoprime, while they were sensitive to nitrofurantoin, amikacin and cefotaxime (Table 3 ).

Discussion. The present study aimed to evaluate the bacterial profile in bile culture in patients undergoing LC and the association between the presence of bacteria and histopathological features of GB. 
Table 3

Antibiogram for isolated bacteria

\begin{tabular}{|l|c|c|c|c|c|}
\hline Antibiotics & $\begin{array}{c}\text { Escherichia } \\
\text { coli } \\
(\mathbf{1 1})\end{array}$ & $\begin{array}{c}\text { Pseudomonas } \\
\text { aeruginosa } \\
(7)\end{array}$ & $\begin{array}{c}\text { Enterococcus } \\
\text { faecium } \\
(\mathbf{4})\end{array}$ & $\begin{array}{c}\text { Citrobacter } \\
\text { freundii } \\
(\mathbf{3 0})\end{array}$ & $\begin{array}{c}\text { Staphylococcus } \\
\text { epidermidis } \\
(3)\end{array}$ \\
\hline Ampicillin & 10 & 5 & 1 & 2 & 2 \\
$(90.91 \%)$ & $(71.43 \%)$ & $(25 \%)$ & $(66.67 \%)$ & $(66.67 \%)$ \\
\hline Amoxicillin/ & 9 & 6 & 2 & 1 & 1 \\
Clavulanic acid & $(81.82 \%)$ & $(85.41 \%)$ & $(25 \%)$ & $(33.33 \%)$ & $(33.33 \%)$ \\
\hline Penicillin & 11 & 7 & 3 & 3 & 2 \\
\hline Gentamycin & $(100 \%)$ & $(100 \%)$ & $(75 \%)$ & $(100 \%)$ & $(66.67 \%)$ \\
\hline Sulfamethaxazole- & 6 & 1 & 1 & 1 & 2 \\
trimethoprime & $(54.55 \%)$ & $(14.29 \%)$ & $(25 \%)$ & $(33.33 \%)$ & $(66.67 \%)$ \\
\hline Cephalexin & 9 & 4 & 4 & 2 & 2 \\
\hline Cephalothin & $(54.55 \%)$ & $(85.71 \%)$ & $(50 \%)$ & $(66.67 \%)$ & $(33.33 \%)$ \\
\hline Naldixic acid & 9 & 4 & 0 & 1 & 1 \\
\hline Nitrofurantoin & $(81.82 \%)$ & $(57.14 \%)$ & $(0 \%)$ & $(33.33 \%)$ & $(33.33 \%)$ \\
\hline Ciprofloxacin & 6 & 6 & 1 & 1 & 1 \\
& $(54.55 \%)$ & $(85.71 \%)$ & $(25 \%)$ & $(33.33 \%)$ & $(33.33 \%)$ \\
\hline Ceftriaxone & 2 & 4 & 0 & 0 & 0 \\
& $(1.82 \%)$ & $(57.14 \%)$ & $(0 \%)$ & $(0 \%)$ & $(0 \%)$ \\
\hline Amikacin & 7 & 1 & 0 & 2 & 0 \\
& $(72.73 \%)$ & $(71.43 \%)$ & $(0 \%)$ & $(33.33 \%)$ & $(100 \%)$ \\
\hline Cefotaxime & 1 & 5 & 1 & 1 & 1 \\
\hline & $(9.09 \%)$ & $(71.43 \%)$ & $(25 \%)$ & $(33.33 \%)$ & $(33.33 \%)$ \\
\hline
\end{tabular}

According to the present study, the most affected age group was youth during their forties. Many of the previous studies are in accordance with these results. In a recent study, Singh et al. [11] studied the incidence of GB malignancy in 100 Indian patients with cholecystitis. The majority of the patients in this study were in the age group between 40 and 49 years, with a mean age of 44.1 years. The present results are also in concordance with the results obtained by Khanna et al. [12], Tyagi et al. [13], Ali et al. [14], and Channa et al. [15] who reported the mean age of $42.5,43.6$, and 45.3 years, respectively.

On the other hand in the present study, $70 \%$ of patients were female, with male:female ratio 1:2.3. This is in line with Singh et al. [11] who reported that $85 \%$ of their patients were female. Similar results have been reported in the studies of Mathur et al. [16] and Mohan et al. [17] who reported that $86.97 \%$ and $86.54 \%$ of patients were female, respectively. The female sex hormones may have a role in promoting the formation of gallstones.
According to the present study, $38.75 \%$ of bile samples were positive for bacteria, where $E$. coli $(13.75 \%)$ and $P$. aeruginosa $(8.75 \%)$ were the most common pathogens. In a similar study, Morris-Stiff et al. [9] investigated the prevalence of bactibilia in patients undergoing LC. The overall incidence of bactibilia was found to be $20 \%$, where E. coli and $P$. aeruginosa were the most prevalent pathogens.

Culture-based studies demonstrated that 9\% and $54 \%$ of patients with cholelithiasis without infection had a positive bacterial culture $[6,18]$. Two studies addressing this issue reported conflicting results. Wu et al. [19] reported a very high rate of colonization $(100 \%)$ and suggested the presence of a bile core microbiome. The other study found the rate of colonization to be only $13 \%$ [20].

Interestingly the present rate of bacterial infection may be underestimated. That is because a large proportion of bacteria in bile ducts are anaerobic and difficult to be cultured, so had a slow growth rate, and negative results for 
their growth in the laboratory do not deny their presence in the infection site nor that they are of less clinical significance. On the other hand, it is also appropriate to indicated that profuse growth does not necessarily reflect in vivo dominance but might as well reflect a microbe's ability to survive and compete during transportation and culturing processes [2].

In the present study, bacterial infection significantly associated with acute cholecystitis with mucocele and empyema. The presence of bacterial colonization in GB mucocele could be a result rather than cause. That is because the GB stasis can be due to cholelithiasis and can lead to the colonization of bacteria, which contributes to the inflammatory response [21]. On the other hand, GB empyema is a direct result of bacterial invasion and colonization. It is often associated with several pathogenic organisms including E. coli, S. aureus, and Bacteroides [22].

The present study revealed a high resistance rate of the isolated bacteria for most available antibiotics. Almost similar results were obtained by previous local study including women with urinary tract infection. Most of the isolated uropathogens had very high degree of resistance to penicillin, ampicillin, sulfamethaxazole-trimethoprime, cephalothin, ceftriaxone and cefotaxime sodium [23]. Globally, the present rates of resistance are much higher than that reported in other countries such as Taiwan and Italy $[24,25]$. The relatively high rate of bacterial resistance in Iraq is mainly attributed to non-restricted use of antibiotics.

Patients were followed up form two weeks after surgery for postoperative complication. Infection of surgical wound was reported in two patients. However, the isolated bacteria ( $S$. aureus) were unrelated to that isolated from bile.

Generally, these data indicate the importance of bacterial infection of GB as far as more than one third of patients with cholelithiasis were positive for bacterial culture. Bacterial infection of stoned GB is associated with the development of empyema. Thus, prophylactic antibiotic therapy is recommended for patients undergoing cholecystectomy due to GB stone.

Conflict of interest. The authors declare no conflict of interest.

Authors' Declaration. The authors hereby declare that the work presented in this article is original and that any liability for claims relating to the content of this article will be borne by them.
Acknowledgement. The authors highly appreciate the great help of all Al-Dewaniya Teaching Hospital/Department of Surgery for their help during the sample collection.

Financial support and sponsorship. Selffunding.

\section{БАКТЕРІАЛЬНИЙ ПРОФІЛЬ ЖОВЧІ ПАЦІЕНТІВ, ЯКИМ ПРОВОДИТЬСЯ ХОЛЕЦИСТЕКТОМІЯ}

\section{Ф. Абуд Чалооб}

Технічний інститут Аль-Діванія, Технічний університет Аль-Фурат Аль-Аусат, вул. Вавилон-Наджаф, Наджаф, 54003, Ірак

Резюме

Лапароскопічна холецистектомія $є$ найбільш розповсюдженою плановою хірургічною операцією в загальній хірургії. Існують дискусії щодо корисності профілактичної антибіотикотерапії після холецистектомії. Метою дослідження було встановити наявність мікроорганізмів у жовчі пацієнтів після лапароскопічної холецистектомії. Методи. У цьому дослідженні взяли участь 80 пацієнтів, які пройшли лапароскопічну холецистектомію. Усі зразки жовчного міхура відправляли на гістологічну експертизу. Зразок жовчі кожного пацієнта культивували на бульйоні з серцево-мозковим екстрактом, агарі MacConkey та шоколадному агарі. Для ідентифікації виділених бактерій використовували індекси аналітичного профілю. Результати. Було виявлено шість гістопатологічних відхилень, серед яких хронічний холецистит був найпоширенішою аномалією $(58,75 \%)$, рідше зустрічався гострий холецистит з мукоцеле $(11,25 \%)$. Тридцять один зразок жовчі $(38,75 \%)$ був позитивним щодо росту бактерій. Серед бактеріальних ізолятів із зразків жовчі були ідентифіковані Escherichia coli - 13,75\%, Pseudomonas aeruginosa - 8,75\%, Enterococcus faecium - 5\%, Citrobacter freundii - 3,7\%, Staphylococcus epidermidis - 3,75\%, Lactobacillus gasseri - 2,5\% та Bifidobacterium - 1,25\%. Бактеріальна колонізація жовчного міхура була значною мірою пов'язана 3 гострим холециститом 3 мукоцеле та емпіємою. Висновки. Більше третини пацієнтів 3 жовчнокам'яною хворобою мають позитивні результати бактеріального посіву жовчі. Бактеріальна інфекція жовчного міхура при жовчнокам'яній хворобі пов'язана з розвитком емпієми. Таким чи- 
ном, пацієнтам, яким проводять холецистектомію через наявність каменів у жовчному міхурі рекомендована профілактична антибіотикотерапія.

1. Kimura Y, Takada T, Kawarada Y, Nimura Y, Hirata K, Sekimoto M, et al. Definitions, pathophysiology, and epidemiology of acute cholangitis and cholecystitis: Tokyo guidelines. J Hepatobiliary Pancreat Surg 2007; 14(1):15-26.

2. Dyrhovden R, Ovrebo KK, Nordahl MV, Nygaard RM, Ulvestad E, Kommedal O. Bacteria and fungi in acute cholecystitis. A prospective study comparing next generation sequencing to culture. Journal of Infection. 2020; 80(1):16-23.

3. Brody LA, Brown KT, Getrajdman GI. Clinical factors associated with positive bile cultures during primary percutaneous biliary drainage. Journal of Vascular and Intervention Radiology. 1998; 9:572-578.

4. Petakovic G, Korica M, Gavrilovic S. Bacteriologic examination of gallbladder contents. Med Pregl. 2002; 55:225-228.

5. Flores C, Maguilnik I, Hadlich E, Goldani LZ. Microbiology of choledochal bile in patients with choledocholithiasis admitted to a tertiary hospital. J Gastroenterol Hepatol 2003; 18:333-336.

6. Abeysuriya V, Deen KI, Wijesuriya T, Salgado SS. Microbiology of gallbladder bile in uncomplicated symptomatic cholelithiasis. Hepatobiliary Pancreat Dis Int 2008; 7 (6):633-637.

7. Groen JV, Droogh DHn, Vahrmeijer AL, Bonsing BA, Mieog JS. Clinical implications of bile cultures obtained during pancreatoduodenectomy: a cohort study and meta-analysis. HPB (Oxford). 2020; 10:S1365-182X (20)31246-6.

8. Capoor MR, Nair D, Khanna RG, Krishna SV, Chintamani MS, Aggarwal P. Microflora of bile aspirates in patients with acute cholecystitis with or without cholelithiasis: a tropical experience. Braz J Infect Dis 2008; 12(3):222-225.

9. Morris-Stiff GJ, O’Donohue P, Ogunbiyi S, Sheridan WG. Microbiological assessment of bile during cholecystectomy: is all bile infected? HPB (Oxford). 2007; 9(3):225-228.

10. Kawai M, Iwahashi M, Uchiyama K, Ochiai M, Tanimura H, Yamaue H. Gram-positive cocci are associated with the formation of completely pure
Ключові слова: холецистектомія, бактеріальна колонізація жовчного міхура.

cholesterol stones. Am J Gastroenterol. 2002; 97(1):83-8.

11. Singh A, Singh G, Kaur K, Goyal G, Saini G, Sharma D. Histopathological Changes in Gallbladder Mucosa Associated with Cholelithiasis: A Prospective Study. Niger J Surg. 2019; 25(1):21-25.

12. Khanna R, Chansuria R, Kumar M, Shukla HS. Histological changes in gallbladder due to stone disease. Indian J Surg. 2006; 68:201-4.

13. Tyagi SP, Tyagi N, Maheshwari V, Ashraf SM, Sahoo P. Morphological changes in diseased gallbladder: A study of 415 cholecystectomies at Aligarh. J Indian Med Assoc. 1992; 90:178-81.

14. Ali SA, Tahir SM, Soomoro AG, Siddiqui AJ, Memon AS. Open cholecystectomy without intraperitoneal drainage. J Ayub Med Coll Abbottabad. 2010; 22(2):29-31.

15. Channa NA, Soomro AM, Ghangro AB. Cholecystectomy is becoming an increasingly common operation in Hyderabad and adjoining areas. Rawal Med J. 2007; 32(2):128-130.

16. Mathur SK, Duhan A, Singh S, Aggarwal M, Aggarwal G, Sen R, et al. Correlation of gallstone characteristics with mucosal changes in gallbladder. Trop Gastroenterol. 2012; 33:39-44.

17. Mohan H, Punia RP, Dhawan SB, Sekhon MS. Morphological spectrum of gallstone disease in 1100 cholecystectomies in North India. Indian J Surg. 2005; 67:140-142.

18. Darkahi B, Sandblom G, Liljeholm H, Videhult P, Melhus A, Rasmussen IC. Biliary microflora in patients undergoing cholecystectomy. Surg Infect. $2014 ; 15$ (3):262-5.

19. Wu T, Zhang Z, Liu B, Hou D, Liang Y, Zhang J, et al. Gut microbiota dysbio-sis and bacterial community assembly associated with cholesterol gallstones in large-scale study. BMC Genom. 2013; 14:669.

20. Tsuchiya Y, Loza E, Villa-Gomez G, Trujillo CC, Baez S, Asai T, et al. Metage- nomics of microbial communities in gallbladder bile from patients with gallbladder cancer or cholelithiasis. 
Asian Pac J Cancer Prev. 2018; 19 (4):961-967.

21. Jones MW, Deppen JG. Gallbladder Mucocele. Stat Pearls 2021. Available from: https://www. ncbi.nlm.nih.gov/books/NBK513282/

22. Waheed A, Mathew G, King KC. Gallbladder empyema. Stat Pearls 2019. https://www.ncbi. nlm.nih.gov/books/NBK459333/

23. Saeed CH, Al-Otraqchi KI, Manssor IY. Prevalence of urinary tract infections and antibiotics susceptibility pattern among infants and young children in Erbil city Zanco. J Med Sci. 2015; 19(1):915-922.
24. Yoshida M, Takada T, Kawarada Y, Tanaka A, Nimura Y, Gomi H, et al. Antimicrobial therapy for acute cholecystitis: Tokyo Guidelines. J Hepatobiliary Pancreat Surg. 2007; 14(1):8390.

25. Coccolini F, Sartelli M, Catena F, Montori G, Di Saverio S, Sugrue M, et al. Antibiotic resistance pattern and clinical outcomes in acute cholecystitis: 567 consecutive worldwide patients in a prospective cohort study. Int J Surgery. 2015; $21: 32-37$.

Received 12.05.2021 